\title{
A Holocene tephra layer within coastal aeolian deposits north of Caleta Olivia (Santa Cruz Province, Argentina)
}

\author{
*Giovanni Zanchetta1, Marta Pappalardo1, Alessio Di Roberto², Monica Bini ${ }^{1,}$, Ilenia Arienzo ${ }^{4}$, \\ Ilaria Isola ${ }^{2}$, Adriano Ribolini ${ }^{1}$, Gabriella Boretto ${ }^{5}$, Enrique Fuck ${ }^{6}$, Daniela Mele ${ }^{7}$, \\ Massimo D’Orazio ${ }^{1}$, Fabio Marzaioli ${ }^{8}$, Isabella Passariello ${ }^{8}$
}

\author{
${ }^{I}$ Dipartimento di Scienze della Terra, University of Pisa, Via S. Maria 53, 56126 Pisa, Italy. \\ zanchetta@dst.unipi.it; marta.pappalardo@unipi.it; adriano.ribolini@unipi.it; massimo.dorazio@unipi.it \\ ${ }^{2}$ Istituto Nazionale di Geofísica e Vulcanologia, Sezione di Pisa, Via della Faggiole 32, 56126 Pisa, Italy. \\ alessio.diroberto@ingv.it; ilaria.isola@ingv.it \\ ${ }^{3}$ Istituto Nazionale di Geofísica e Vulcanologia (INGV), Via Vigna Murata 605, 00143 Roma. \\ bini@dst.unipi.it_ \\ ${ }^{4}$ Istituto Nazionale di Geofísica e Vulcanologia, Sezione di Napoli Osservatorio Vesuviano, via Diocleziano 328, Napoli, Italy. \\ ilenia.arienzo@ingv.it \\ ${ }^{5}$ Centro de Investigaciones en Ciencias de la Tierra (CICTERRA), Consejo Nacional de Investigaciones Cientificas y Técnicas \\ (CONICET) Av. Vélez Sársfield 1611, Edificio CICTERRA, $1^{\circ}$ piso, of. 18, X5016CGA, Ciudad Universitaria, Córdoba, Argentina. \\ gmboretto@yahoo.com.ar \\ ${ }^{6}$ Centro de Estudios Integrales de la Dinámica Exógena (CEIDE), Universidad Nacional de La Plata, Ingea Ingeniería y Gestión \\ Ambiental (INGEA), calle 64 No. 3, 1900 La Plata, Argentina. \\ efucks@fcnym.unlp.edu.ar \\ ${ }^{7}$ Dipartimento di Scienze della Terra e Geoambientali, Università di Bari, Via Orabona 4, Bari, 70125, Italy. \\ daniela.mele@uniba.it \\ ${ }^{8}$ CIRCE, Department of Mathematics and Physics, Second University of Naples, Viale Carlo III di Borbone, 153, 81020, Caserta, Italy. \\ fabio.marzaioli@unicampania.it; isabella.passariello@unina2.it \\ *Corresponding author: zanchetta@dst.unipi.it
}

\begin{abstract}
In this paper we illustrate the stratigraphy, geochronology, and geochemistry (major, minor, trace elements and Sr-isotopes) of a Holocene tephra layer found within coastal sedimentary deposits north of Caleta Olivia (Santa Cruz Province, Argentina). The stratigraphic succession comprises beach deposits with basal erosive surface resting on the local substrate ("Formación Patagonia") followed by a poorly developed paleosoil. The paleosoil is covered by a lenticular finegrained (Md $\varphi: 5.2,0.027 \mathrm{~mm}$ ), well sorted $(\sigma \varphi: 1.2)$ volcanic ash layer and aeolian sands. The geochemical composition of shard fragments points to an origin from the Hudson volcano, located in the southern Andes, $c a$. $400 \mathrm{~km}$ to the west. The geochemistry, Sr-isotopes and the radiometric constraints (younger than the age of the underlying marine layer dated at $c a$. 4,100 a cal BP) further allow correlating this tephra with the so-called $\mathrm{H}_{2}$ eruption ( $c a$. 3,900 a cal BP). This finding is of interest owing to the poor preservation potential of tephra within the Late Holocene sedimentary deposits of the Atlantic coast of Patagonia and represents the first finding of $\mathrm{H}_{2}$ eruption in this area, improving our knowledge of the dispersion of the fine-grained distal deposit of the Hudson volcanic explosive activity, thus allowing a better estimate of the eruptive dynamics and the risks associated with the Hudson volcano.
\end{abstract}


RESUMEN. Una capa de tefra holocena intercalada en los depósitos eólicos costeros ubicados al norte de Caleta Olivia (Provincia de Santa Cruz, Argentina). Este artículo aborda la estratigrafía, geocronología y geoquímica (elementos mayoritarios, minoritarios, trazas e isótopos de $\mathrm{Sr}$ ) de un nivel de tefra holocena que forma parte de una secuencia de sedimentos costeros ubicados al norte de Caleta Olivia (provincia de Santa Cruz, Argentina). La secuencia comprende depósitos sedimentarios que se disponen sobre una superficie basal erosiva que suprayace al sustrato local ("Formación Patagonia"), y continúa esta secuencia con un paleosuelo de escaso desarrollo. El paleosuelo está cubierto por una capa lenticular de cenizas volcánicas de grano fino (Md $\varphi: 5,2,0,027 \mathrm{~mm})$, bien seleccionada $(\sigma \varphi: 1,2)$ y arenas eólicas. La composición geoquímica de los shards indica que esta tefra se originó en el volcán Hudson, ubicado en los Andes del sur, a aproximadamente $400 \mathrm{~km}$ hacia el oeste. La geoquímica, los isótopos de $\mathrm{Sr}$ y las restricciones radiométricas (más joven que la edad de la capa marina que la subyace, fechada en aproximadamente 4.100 a cal AP) permiten correlacionar esta tefra con la denominada erupción $\mathrm{H}_{2}$ de dicho volcán (ocurrida aproximadamente 3.900 a cal AP). Este hallazgo es de interés debido al escaso potencial de preservación de los depósitos de tefra dentro de las secuencias sedimentarias costeras del Holoceno Tardío, en la costa atlántica de Patagonia y representa el primer hallazgo del evento eruptivo $\mathrm{H}_{2}$ en esta área, lo cual contribuye a mejorar el conocimiento sobre la dispersión de la tefra generada por la actividad volcánica explosiva del volcán Hudson, lo que permite una mejor estimación de la dinámica eruptiva y los riesgos asociados con este volcán.

Palabras clave: Tefra, Volcán Hudson, Erupción $\mathrm{H}_{2}$, Holoceno, Patagonia, Caleta Olivia.

\section{Introduction}

The reconstruction of volcanic ashes dispersion related to past explosive volcanic eruptions represents a fundamental tool for correctly estimating volcanic eruptive dynamics, frequency and associated risks (e.g., Stern, 2008; Fontijn et al., 2014; Rawson et al., 2015; Stern et al., 2015; Sulpizio et al., 2014; Naranjo et al., 2017; Del Carlo et al., 2018). Moreover, the study of distal tephra layers is an invaluable tool for correlating different natural archives (e.g., Zanchetta et al., 2008, 2018a; Blockley et al., 2014) and solving different issues in Quaternary stratigraphy, archaeology and palaeoclimatology (e.g., Lowe, 2011; Lowe et al., 2012; Prieto et al., 2013; Zanchetta et al., 2018b, 2019). Southern South America is an area where studies on distal tephrostratigraphy have been systematically addressed for the number of potentially active volcanoes (e.g., Stern, 2004). The Hudson volcano is a good case, which exemplifies the potential volcanic risk of the region. On 12-14 August 1991 the Hudson volcano erupted (Naranjo, 1991; Naranjo et al., 1993) affecting the central and southernmost part of the Patagonia. The ash of the Plinian eruption covered an area of $c a .100,000 \mathrm{~km}^{2}$ (Fig. 1) heavily damaging local people, cattle and economy (Scasso et al., 1994). The arid and windy climatic condition of the Patagonia region and its strongly eroded soil owing to overgrazing allowed a continuous remobilization of the volcanic ashes for years, prolonging their negative impact on the environment and economy (Inbar et al., 1995). This clearly indicates that the impact of the volcanic explosive eruptions is exacerbated in marginal land experiencing a strong human pressure. Archeological investigations also suggest that a different Plinian eruption from the Hudson volcano, the so-called $\mathrm{H}_{1}$, occurred $c a$. 7,750 a cal BP (Stern, 1991, 2008; Naranjo and Stern, 1998), impacted hunter-gatherers populations of southern Patagonia and Tierra del Fuego (Prieto et al., 2013).

Stratigraphic works in southern Patagonia and Tierra del Fuego (e.g., Daga et al., 2010, 2014; Stern, 1991, 2008; Naranjo and Stern, 1998; Stern et al., 2011, 2015, 2016; Fontijn et al., 2014; Rawson et al., 2015; Naranjo et al., 2017; Del Carlo et al., 2018) have shown that recurrent explosive volcanic activity mantled the landscape with different tephra thickness also far from the volcanic centers. This unequivocally indicates that distal tephra dispersion represents a real and immanent natural hazard for these marginal lands, which host population and important economic activities. However, most of the researches on recurrence of tephra layers are restricted to the Andean to peri-Andean region (e.g., Daga et al., 2010, 2014; Stern et al., 2011, 2015, 2016; Fontijn et al., 2014; Weller et al., 2015, 2019; Watt et al., 2013) and studies along the Atlantic coast of Patagonia are particularly scarce (Del Carlo et al., 2018). This can be related to the specific environment of this region characterised by dry and windy conditions with a steppic vegetation, which renders preservation of volcanic ashes very occasional. Indeed, as observed by Naranjo et al. (2017) 


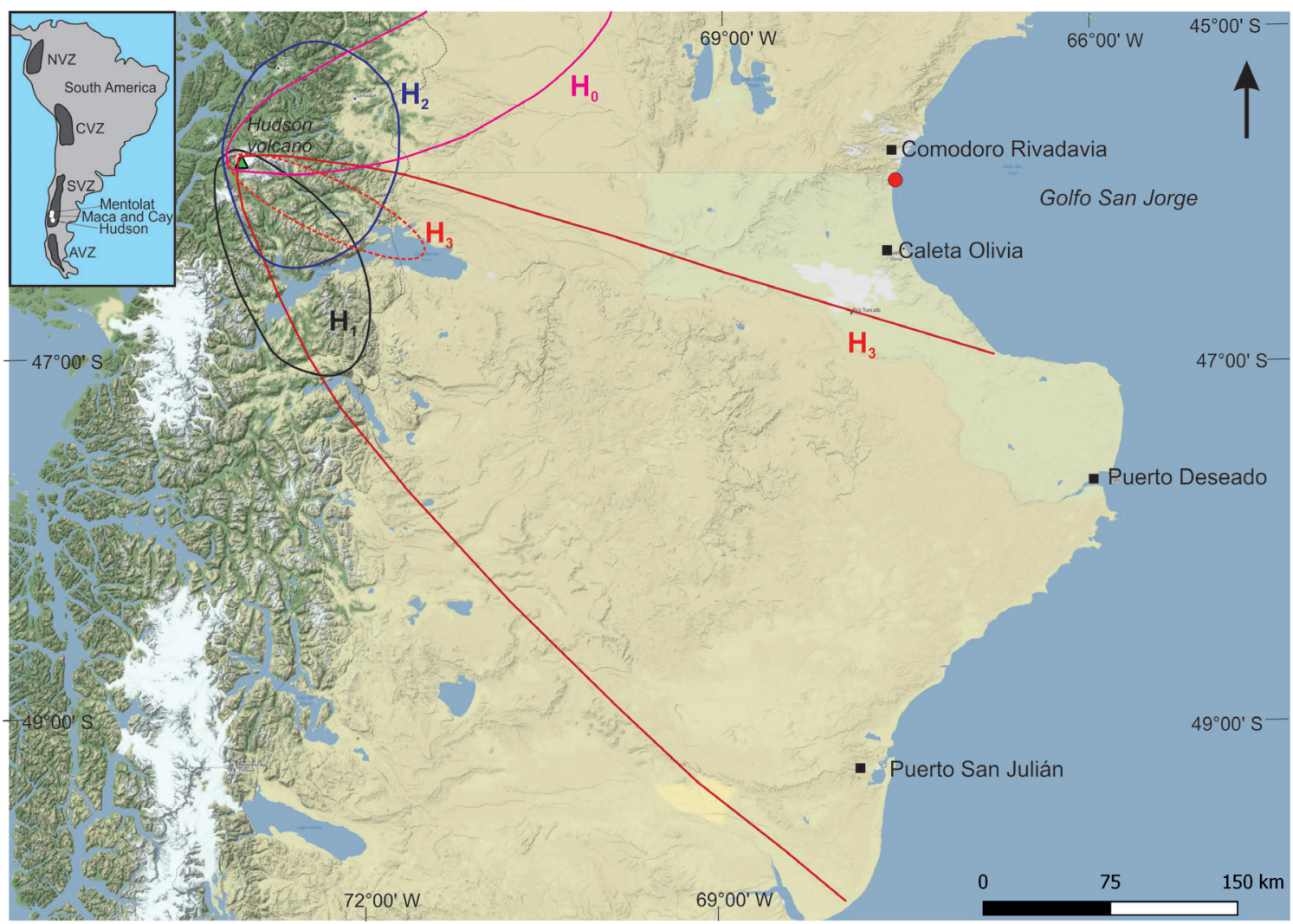

FIG. 1. Location map. Dispersion for major Hudson volcano explosive eruptions: of $1991 \mathrm{AD}\left(\mathrm{H}_{3}\right)$ eruption (after Scasso et al., 1994); Dispersion for $\mathrm{H}_{2}$ eruption (after Naranjo and Stern, 1998); Dispersion for $\mathrm{H}_{1}$ eruption (after Naranjo and Stern, 1998; Stern, 2008), Dispersion from $\mathrm{H}_{0}$ (after Weller et al., 2014). Isopachs for $\mathrm{H}_{2}, \mathrm{H}_{1}, \mathrm{H}_{0}$ represent $10 \mathrm{~cm}$, for $\mathrm{H}_{3}$ continous line $0.1 \mathrm{~cm}$, dotted line $10 \mathrm{~cm}$ (after Scasso et al., 1994 and Naranjo and Stern, 1998). NVZ: North Volcanic Zone; CVZ: Central Volcanic Zone; SVZ: South Volcanic Zone; AVZ: Austral Volcanic Zone. Red dot: study area.

the accumulation and preservation of tephra layers are mainly a function of the volume of the dispersed pyroclasts and the presence of retainer agents such as the presence of mature forests that prevent aeolian reworking of the fallen ash and lapilli. Therefore, in the Atlantic coast of Patagonia the finding of tephra is exceptional but can be very useful for complementing more proximal data giving information on ash dispersion and for a better estimation of the total volume of an eruption.

In this study, we report for the first time the finding of a tephra layer from Hudson volcano within raised coastal Holocene sedimentary deposits of the Golfo San Jorge, north of Caleta Olivia (Fig. 1). This finding gives further data to improve the knowledge on the dispersion of the product of this volcano and for reconstructing a tephra "lattice" at a regional scale for Quaternary stratigraphic work.

\section{The study area}

The study area is located within the Golfo San Jorge basin between 44 and $47^{\circ} \mathrm{S}$ and $66^{\circ}$ and $71^{\circ} \mathrm{W}$, in central Patagonia, southern Argentina (Fig. 1). The Golfo San Jorge is an intracratonic basin placed in between two structural highs, namely the Somuncurá Massif (also known as Norpatagónico Massif) to the north and the Deseado Massif to the south (Ramos and Ghiglione, 2008). These positive elements represent the pre-Cretaceous basement of the basin. The infilling of the basin consists of marine to continental sedimentary successions spanning from Cretaceous to Quaternary (Sylwan, 2001). Most of the outcrops in the studied area are dominated by the neogenic marine deposits of the Formación Patagonia and Formación Santacruz (e.g., Feruglio, 1950; Figari et al., 2002). During the Late Pliocene and the Quaternary successions of fluvial 
to glacio-fluvial gravels and sands formed extensive covers organized at different altitudinal level and paleovalley (often known as Rodados Patagónicos or Rodados Tehuelches, e.g., see the extensive review of Panza, 2002). Since the Middle Pleistocene, in the coastal area, successions of marine terraces with prevailing gravelly deposits developed during the phases of interglacial marine highstand (Rostami et al., 2000). A system of Holocene raised beaches started to form since $c a$. 6,000 a cal BP organised by successions of beach ridges and littoral terraces discontinuously preserved along the coast (e.g., Bini et al., 2014, 2018; Codignotto et al., 1988; Ribolini et al., 2011; Schellmann and Radtke, 2010; Isla and Bujalesky, 2008; Isola et al., 2011; Zanchetta et al., 2012a, 2014).

The local climate is dominated by the southern Westerlies (Garreaud et al., 2009) and can be considered temperate arid (mesothermal). The mean annual precipitations are $c a .230 \mathrm{~mm}$, mostly concentrated during the cold season. The average annual temperature is $12.7^{\circ} \mathrm{C}$, with the maximum in January $\left(19.1^{\circ} \mathrm{C}\right)$ and minimum in July $\left(6.6^{\circ} \mathrm{C}\right)$. The coast is dominated by a meso-to-macrotidal regime (Isla and Bujalesky, 2008).

\section{Materials and Methods}

The stratigraphic section was described and measured during a field survey carried out in February 2010. The ash samples were wrapped in a plastic bags and transported to the laboratory. Then they were dried at room temperature, observed and described under a binocular microscope. A fraction of the bulk samples was dried and embedded in epoxy resin, coated with graphite and screened for glass shards using a scanning electron microscope (SEM) at the Earth Sciences Department of the University of Pisa. Energy-dispersive spectrometry (EDS) of glass shards was performed using an EDAX-DX micro-analyzer mounted on a Philips SEM 515 (operating conditions: $20 \mathrm{kV}$ acceleration voltage, 100 s live time counting, 200-500 nm beam diameter, 2100-2400 shots $\mathrm{s}^{-1}$, ZAF correction). The ZAF correction procedure does not include natural or synthetic standards for reference and requires analysis normalization at a given value (chosen at 100\%). Detailed discussion on the SEM-EDS performance, inter-calibration trials and standards can be found in Marianelli and Sbrana (1998), Cioni et al. (1997), Caron et al. (2012), Vogel et al. (2010), Zanchetta et al. (2012b). According to the intercalibration, analytical precision is $0.5 \%$ for oxides abundances higher than $15 \mathrm{wt} \%, 1 \%$ for abundances around $5 \mathrm{wt} \%, 5 \%$ for abundances of $1 \mathrm{wt} \%$, and less than $20 \%$ for abundances close to the detection limit (around $0.5 \mathrm{wt} \%$ ). During this work, we used two standards whose chemistry has been accurately controlled by XRF analyses and certified (Albite in-house standard and CFA47, Cioni et al., 1997; Marianelli and Sbrana, 1998) and routinely analyzed in the Pisa laboratory in the last 15 years (e.g., Zanchetta et al., 2018b).

To avoid alkali loss by diffusion a window spot ca. $10 \mu \mathrm{m}$ wide was used. In some cases, due to the different shapes and sizes of the glass shards a smaller beam size was used. The reduction of the size defocuses the beam and this may affect the analytical data due to the complex combination of element mobility and sample damage (Hunt and Hill, 2001). However, this potential bias is minimized by analyzing several shards from the same sample (Zanchetta et al., 2012b). Table 1 shows the data.

The concentrations of $\mathrm{Li}, \mathrm{Be}, \mathrm{Sc}, \mathrm{V}, \mathrm{Cr}, \mathrm{Co}, \mathrm{Ni}$, $\mathrm{Cu}, \mathrm{Zn}, \mathrm{Ga}, \mathrm{Rb}, \mathrm{Sr}, \mathrm{Y}, \mathrm{Nb}, \mathrm{Mo}, \mathrm{Cs}, \mathrm{Ba}$, rare earth elements (REEs), $\mathrm{Ta}, \mathrm{W}, \mathrm{Pb}$, Th and $\mathrm{U}$ were determined on a bulk sample (WP542) by inductively coupled plasma-mass spectrometry (Perkin-Elmer NexION 300x) at the Dipartimento di Scienze della Terra (University of Pisa). The complete sample dissolution was obtained by repeated treatment with concentrated $\mathrm{HF}+\mathrm{HNO}_{3}$ (suprapure grade) on a hotplate. International geochemical reference rocks were used in calibration and quality check. The correction procedure includes (i) blank subtraction, (ii) instrumental drift correction using internal standardization ( $\mathrm{Rh}, \mathrm{Re}, \mathrm{Bi}$ at $20 \mathrm{ng} / \mathrm{ml}$ ), and (iii) oxide-hydroxide interference correction. The analytical precision is better than 5\% RSD (Relative Standard Deviation) for all elements, except $\mathrm{Sc}, \mathrm{Cr}$, $\mathrm{Ni}, \mathrm{Cu}, \mathrm{Zn}$ (10-15\% RSD). Table 2 shows the data. $\mathrm{Sr}$ isotope composition was determined by thermal ionization mass spectrometry at the Istituto Nazionale di Geofisica e Vulcanologia, Osservatorio Vesuviano (INGV, Naples, Italy), using a ThermoFinnigan Triton TI multicollector mass spectrometer on a glass shardrich sample. $0.2 \mathrm{~g}$ of sample were leached several times with cold $6 \mathrm{~N} \mathrm{HCl}$ for $10 \mathrm{~min}$, and then rinsed in pure Milli $\mathrm{Q}{ }^{\circledR} \mathrm{H}_{2} \mathrm{O}$. After dissolution, $\mathrm{Sr}$ was separated by conventional ion-exchange chromatographic techniques. The Sr blank was on the order of $0.1 \mathrm{ng}$ during the period of chemistry processing. 


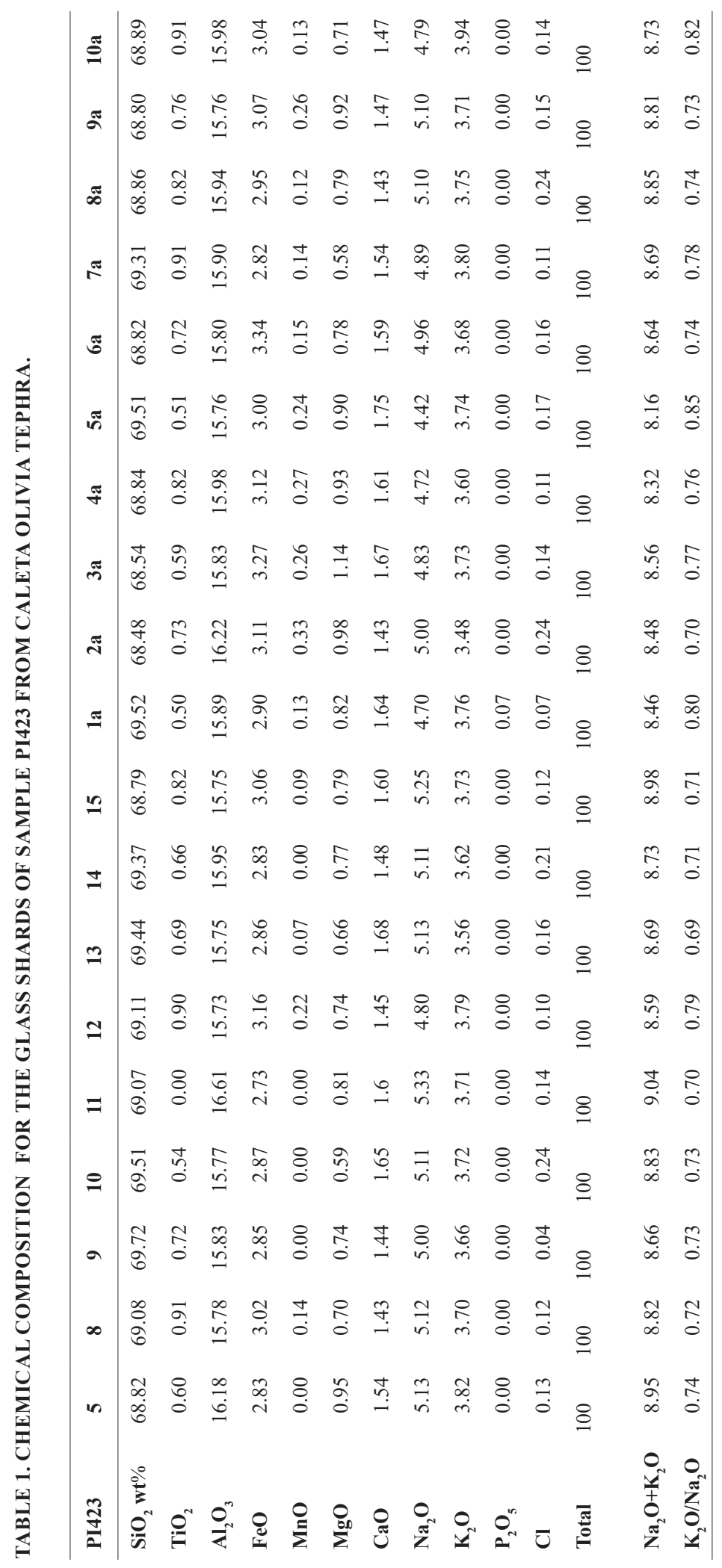


TABLE 2. TRACE ELEMENTS AND ${ }^{87} \mathrm{Sr} /{ }^{86} \mathrm{Sr}$ DATA FOR WHOLE ROCK ANALYSIS OF SAMPLE WP542 FROM CALETA OLIVIA TEPHRA. $(*)$

\begin{tabular}{|c|c|c|c|c|}
\hline $\begin{array}{c}\text { Element } \\
(\mu \mathrm{g} / \mathrm{g})\end{array}$ & WP542 & WSE & WSE REF & uncertainty \\
\hline $\mathbf{L i}$ & 19.2 & 13.9 & 13.5 & 1 \\
\hline $\mathrm{Be}$ & 2.97 & 1.07 & 1.1 & 0.14 \\
\hline Ga & 18.4 & 21.4 & 21.6 & 1 \\
\hline $\mathbf{R b}$ & 79 & 25.4 & 25.8 & 0.76 \\
\hline $\mathrm{Sr}$ & 204 & 412 & 408 & 8.6 \\
\hline Y & 48 & 32.0 & 31.8 & 1.1 \\
\hline $\mathbf{Z r}$ & 471 & 204 & 204 & 5.9 \\
\hline $\mathrm{Nb}$ & 19.3 & 17.9 & 17.9 & 0.74 \\
\hline Mo & 1.99 & 3.27 & 3.54 & 0.36 \\
\hline Cs & 1.93 & 0.46 & 0.48 & 0.014 \\
\hline Ba & 756 & 346 & 335 & 11 \\
\hline La & 47 & 26.7 & 26.6 & 0.45 \\
\hline $\mathrm{Ce}$ & 101 & 61 & 60 & 1.3 \\
\hline Pr & 12.2 & 7.9 & 7.7 & 0.16 \\
\hline Nd & 47 & 33.3 & 32.8 & 0.51 \\
\hline Sm & 9.3 & 9.3 & 8.7 & 0.18 \\
\hline Eu & 2.13 & 2.26 & 2.21 & 0.057 \\
\hline Gd & 8.6 & 7.2 & 7.2 & 0.2 \\
\hline Tb & 1.31 & 1.11 & 1.08 & 0.024 \\
\hline Dy & 7.8 & 6.2 & 6.1 & 0.091 \\
\hline Ho & 1.63 & 1.20 & 1.18 & 0.026 \\
\hline $\mathbf{E r}$ & 4.9 & 3.16 & 3.07 & 0.056 \\
\hline Tm & 0.75 & 0.44 & 0.42 & 0.01 \\
\hline $\mathbf{Y b}$ & 4.8 & 2.52 & 2.51 & 0.032 \\
\hline Lu & 0.73 & 0.36 & 0.36 & 0.014 \\
\hline Hf & 10.2 & 5.2 & 5.2 & 0.21 \\
\hline Ta & 1.09 & 1.11 & 1.12 & 0.05 \\
\hline $\mathbf{W}$ & 0.51 & 2.92 & - & - \\
\hline $\mathbf{P b}$ & 18.1 & 12.5 & 12.3 & 0.96 \\
\hline Th & 8.2 & 2.98 & 2.99 & 0.086 \\
\hline $\mathbf{U}$ & 1.98 & 0.62 & 0.62 & 0.019 \\
\hline Sc & 12 & 24 & 28 & 1.1 \\
\hline V & 39 & 299 & 336 & 12 \\
\hline $\mathrm{Cr}$ & 5 & 82 & 97 & 4.1 \\
\hline Co & 4 & 41 & 45 & 1.6 \\
\hline $\mathbf{N i}$ & 4 & 50 & 54 & 1.9 \\
\hline $\mathrm{Cu}$ & 51 & 65 & 66 & 3 \\
\hline $\mathbf{Z n}$ & 112 & 111 & 113 & 5.9 \\
\hline${ }^{87} \mathrm{Sr} /{ }^{86} \mathrm{Sr}$ & 0.7044 & - & - & - \\
\hline
\end{tabular}

(*) In the table are also reported the analysis of the reference sample WSE (basalt) with their respective reference values (WSE-REF; taken from http://georem.mpch-mainz.gwdg.de, last visit 15/03/2019).
Measured ${ }^{87} \mathrm{Sr} /{ }^{86} \mathrm{Sr}$ isotope ratio was normalized for within-run isotopic fractionation to ${ }^{86} \mathrm{Sr} /{ }^{88} \mathrm{Sr}=0.1194$. The mean measured values of ${ }^{87} \mathrm{Sr} /{ }^{86} \mathrm{Sr}$ for NISTSRM 987 was $0.710220 \pm 0.000019(2 \sigma)$. The external reproducibility $(2 \sigma)$ is calculated according to Goldstein et al. (2003). Sr isotope ratio was normalized to the recommended values of NIST SRM $987\left({ }^{87} \mathrm{Sr} /{ }^{86} \mathrm{Sr}=0.71025\right)$ standard. ${ }^{87} \mathrm{Sr} /{ }^{86} \mathrm{Sr}$ ratio is reported at the bottom of table 2 .

For characterizing the origin of the tephra layer grain-size analyses were carried out between 3.5 and $9 \varphi(90-2 \mu \mathrm{m})$ at $0.5 \varphi$ intervals, with $\varphi=-\log _{2} \mathrm{~d}$, where $\mathrm{d}$ is the diameter in mm, using a Beckman Coulter Multisizer 4 at the Dipartimento di Scienze della Terra e Geoambientali, University of Bari. The median size $(\mathrm{Md} \varphi)$ and the sorting parameters (Inman, 1952) of each grain-size distribution were calculated using a Fortran 90 code, available into the PYFLOW package (Dioguardi and Dellino, 2014).

A sample of the mitilidae Nacella (Patinigera) deaurata, with joint valves collected below the tephra in the coastal marine layer was selected for radiocarbon dating. The sample was cleaned in an ultrasonic bath with the addition of oxygen peroxide and then gently etched with diluted $\mathrm{HCl}$ to remove any recent carbonate encrustation. Radiocarbon measurement was carried out at the CIRCE laboratory of Caserta, Italy (Terrasi et al., 2007, 2008) and calibrated using the Marine13 curve (Reimer et al., 2015). A better calibration would be obtained using local knowledge of the reservoir effect, which depends on different radiocarbon content of marine waters respect to a simple equilibration with atmospheric ${ }^{14} \mathrm{CO}_{2}$. Indeed, different mixing rate between superficial waters with the tendency of rapid equilibration with atmospheric ${ }^{14} \mathrm{CO}_{2}$ and deeper waters, more depleted in ${ }^{14} \mathrm{CO}_{2}$, for the Southern Atlantic Ocean and, in particular, Patagonia, are not well constrained (Schellmann and Radtke, 2010). For instance, Cordero et al. (2003) have reported reservoir effect from different localities of the Patagonian coast between $c a .42^{\circ} \mathrm{S}$ and $50^{\circ} \mathrm{S}$ ranging between $c a$. 180 and 530 years. Table 3 shows the radiocarbon dating.

\section{Results and discussion}

\subsection{Stratigraphy and lithology of the deposits}

The stratigraphic succession comprises three main lithostratigraphic units (LU, Fig. 2A). The lowest unit (LU-1) correspond to Miocene marine 
TABLE 3. RADIOCARBON DATING OF A MITILIDAE NACELLA (PATINIGERA) DEAURATA SHELL, WITH JOINT VALVES. $(*)$

\begin{tabular}{cccc}
\hline Lab. Code & Field label & $\begin{array}{c}{ }^{14} \mathbf{C ~ a ~ B P} \\
( \pm \mathbf{1} \boldsymbol{\sigma})\end{array}$ & $\begin{array}{c}{ }^{14} \mathbf{C} \text { a cal BP } \\
(\mathbf{\pm} \boldsymbol{\sigma}) \\
(\mathbf{m e d i a n} \\
\text { values) }\end{array}$ \\
\hline DSH8361SH & WP542D & $4058 \pm 36$ & $\begin{array}{c}3967-4216 \\
(4089)\end{array}$
\end{tabular}

(*) Collected in a coastal marine sediment located inmediately below the studied tephra deposit. The radiocarbon age was calibrated using the Marine13 curve in Calib 7.10 (Reimer et al., 2015).

deposits (Formación Patagonia) representing the local substrate. This unit is separated by a planar erosive surface (marine ravinement surface) from LU-2, which is formed by beach deposits. The LU-2 shows $30-50 \mathrm{~cm}$ of a basal shelly layer then becomes sandier showing clear low angle stratification and frequent mollusk fragment (Fig. 2B) typical of beach deposits. Shells are mostly fragmented and only a few specimens preserved joined valves. One of this shells yielded a radiocarbon age of 3,967-4,216 a cal BP (Table 3).

The top of this unit (ca. 20-30 cm) is massive and shows evidence of subaerial bioturbation (root traces) corresponding to a poorly developed soil (Inceptisol) (Fig. 2A, B). A tephra layer, in form of metric lens, lies just above the top of the soil. Above this soil aeolian coarse sands develops embedding the upper part of the tephra layer (LU-3; Fig. 2A, B). The basal part of the tephra is whitish with no evident stratification (massive) and appears almost composed by glass shards (Fig. 3A). These have different size and shape comprising bubble walls and micropumices (Fig. 3A). The shards are almost aphiric and rare quartz and plagioclase are present as loose crystals or crystal fragments. In the upper part, changes in color and evident stratification indicate reworking and mixing with the lithic material of the aeolian sands. The grain-size of the sample taken from the basal part, probably the less contaminated by reworking, shows that it is well sorted and showing a unimodal distribution with a median size value of $5.2 \varphi(0.027 \mathrm{~mm}$; Fig. 3B), suggesting a "primary" deposition. On top of the LU-3 there is an accumulation of marine shells, bone remains and flinstones (shellmidden) and then the present, poorly developed, soil (LU-4; Fig. 2A, B).

\subsection{Chemical, isotopic composition and tephra correlations}

The tephra shards have a relatively homogenous chemical composition (e.g., $\mathrm{SiO}_{2}: 69.09 \pm 0.36 \mathrm{wt} \%$; $\mathrm{K}_{2} \mathrm{O}: 3.71 \pm 0.1 \mathrm{wt} \% ; \mathrm{Na}_{2} \mathrm{O}: 4.97 \pm 0.22 \mathrm{wt} \% ; \mathrm{K}_{2} \mathrm{O} /$ $\mathrm{Na}_{2} \mathrm{O}: 0.75 \pm 0.04$; Table 1 ). In the TAS diagram (Le Bas et al., 1986; Fig. 4A) the glass shards composition plot most in the field of rhyolites at the boundary with the trachydacites. The composition lies in the field of the subalkaline high-K magma series of Peccerillo and Taylor (1976) (not shown).

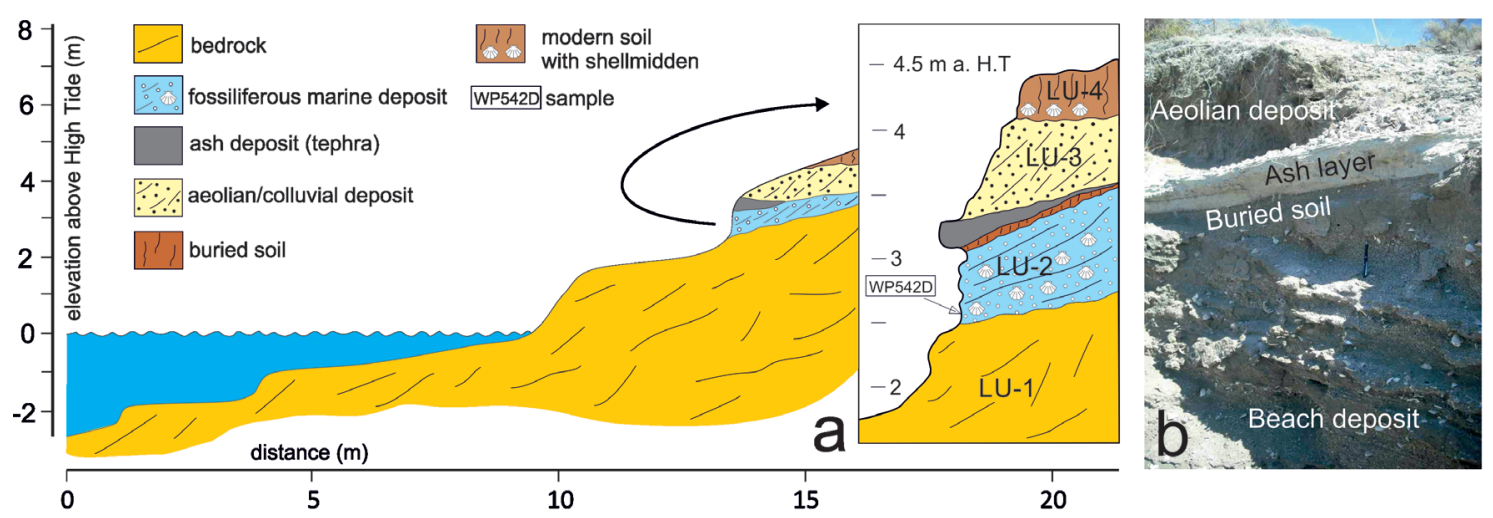

FIG. 2. A. Stratigraphy of the studied section (LU: Lithostratigraphic Units, see the text for details); B. Picture of the stratigraphy including the tephra layer. Note the evidences of stratification in the upper section of the tephra and darker layer indicating mixing with aeolian deposits. 

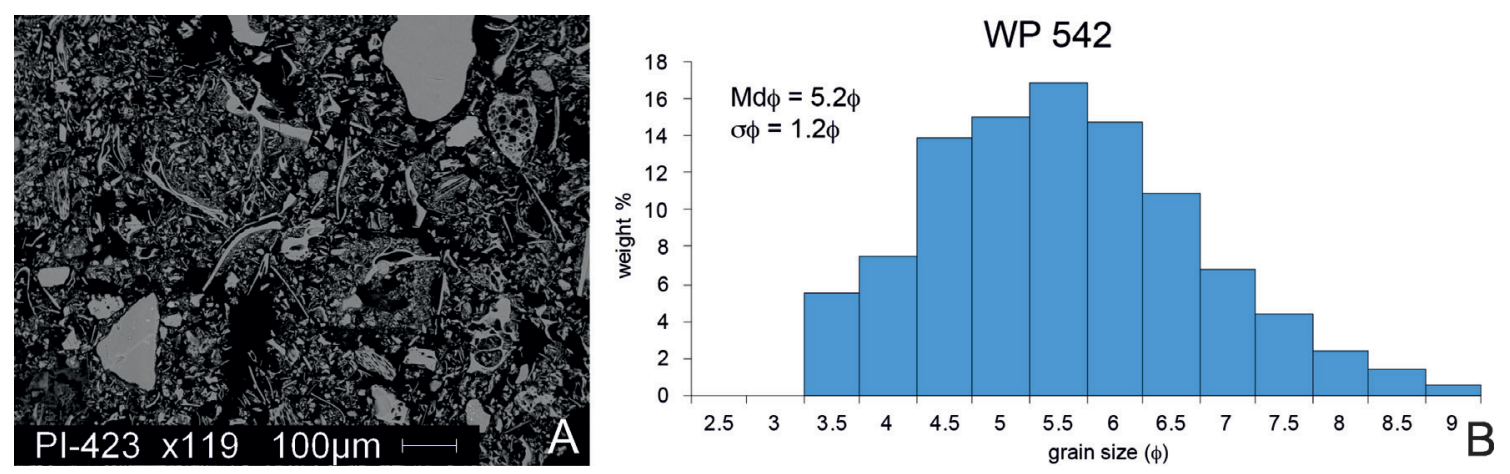

FIG. 3. A. SEM images of the polish section of tephra layer. Note different type of shards and micropumices; B. Grain-size distribution of the basal part of the ash layer (Sample WP542).
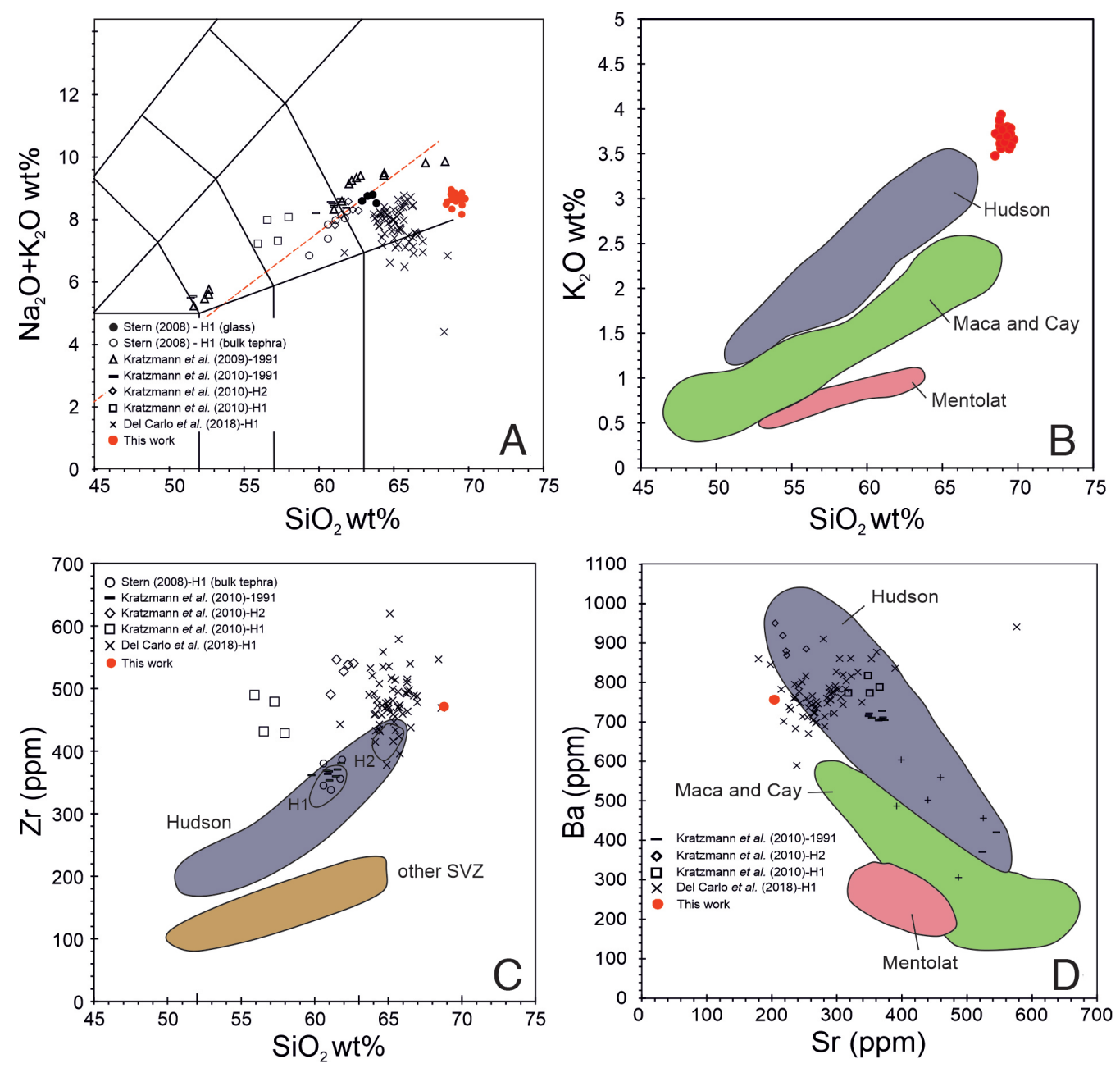

FIG. 4. A. $\mathrm{K}_{2} \mathrm{O}+\mathrm{Na}_{2} \mathrm{O}-\mathrm{SiO}_{2}$ diagram (Le Bas et al., 1986) for tephra samples from $\mathrm{H}_{1}, \mathrm{H}_{2}$ and $\mathrm{H}_{3}$ (1991) Hudson eruptions (segmented line: separation between Subalkaline and Alkaline rocks according to Irvine and Baragar, 1971); B. $\mathrm{K}_{2} \mathrm{O}$ versus $\mathrm{SiO}_{2}$ (compositional field after Stern et al., 2016); C. Zr versus $\mathrm{SiO}_{2}$ (compositional field after Naranjo and Stern, 1998); D. Ba versus $\mathrm{Sr}$ (different compositional field from Weller et al., 2015). For A, B, C and D: red circle: studied tephra. 
Considering the geographical position, the most probable source of this tephra should be located in volcanoes pertinent to the southern edge of the South Volcanic Zone (SVZ) of the Andes as Mentolat, Macá, Cay and Hudson (Stern, 2004; Stern et al., 1984), where the Hudson volcano is one of the most active during the Holocene (Naranjo and Stern, 1998). There have been at least 12 Holocene to Recent explosive eruptions recorded from the Hudson volcano (Naranjo and Stern, 1998) and the major explosive events have been called $\mathrm{H}_{0}, \mathrm{H}_{1}$, $\mathrm{H}_{2}$, and $\mathrm{H}_{3}$ (e.g., Naranjo and Stern, 1998; Weller et al., 2014). They occurred at ca. 17,400 a cal BP $\left(\mathrm{H}_{0}\right.$, Weller et al., 2014), at ca. 7,750 a cal BP $\left(\mathrm{H}_{1}\right)$ (e.g., Prieto et al., 2013), at ca. 3,900 a cal BP $\left(\mathrm{H}_{2}\right)$ (Naranjo and Stern, 1998), and in AD $1991\left(\mathrm{H}_{3}\right)$ (Naranjo and Stern, 1998).

In the $\mathrm{K}_{2} \mathrm{O}-\mathrm{SiO}_{2}$ diagram (Fig. 4B) the glass shards chemical composition lie in the general evolution trend of the Hudson volcanic products and well distinguishable from other nearby volcano products (e.g., Stern et al., 2016). Some of the most used chemical diagram for discriminating volcanoes of the SVZ, like $\mathrm{Zr}-\mathrm{SiO}_{2}$ and $\mathrm{Ba}-\mathrm{Sr}$ (e.g., Stern et al., 2016; Weller et al., 2014, 2019), shows that the glass shards product are all compatible with Hudson volcano (Fig. 4C, D). Data show in figure 4B, C, D are not perfectly coincident with the chemical composition for Hudson volcano defined in the literature. However, it is important to consider that most of these fields have been defined using bulk rock data, rather than the composition of volcanic distal dust-size shard particles. The attribution to the Hudson volcano is straightforwardly confirmed by ${ }^{87} \mathrm{Sr} /{ }^{86} \mathrm{Sr}$ ratio versus $\mathrm{Rb}$ (Naranjo and Stern, 1998; Table 1; Fig. 5), which shows consistently the values within the compositional range of the Hudson volcano.

Our tephra is chemically distinct from $\mathrm{H}_{3}$, which shows a more basic chemical bimodality (Fig. 4A, e.g., Kratzmann et al., 2009), and is decisively older, because the successions is topped by a shell midden, which regionally stopped to form with the arrival of European (Castro, 2008). However, stratigraphy and radiocarbon chronology indicate that our tephra is younger than $c a$. 4,100 a cal BP (Table 3) and cannot be correlated with $\mathrm{H}_{0}$ and $\mathrm{H}_{1}$ eruptions. There is also a significant difference between glass shards chemical composition of $\mathrm{H}_{1}$ tephra unit reported, for instance, by Del Carlo et al. (2018) and our data, which are more felsic (Fig. 4A, also considering the use of EDS in this works, compared to WDS). Therefore, it is reasonable to correlate the Caleta Olivia tephra layer with $\mathrm{H}_{2}$ eruption. The more evolved character of our micro-analyses on shards compared to the original data produced by Naranjo and Stern, 1998, is related to the fact that our chemical data have been obtained on single glass shards and not on bulk samples (Fig. 4A). Further support for the proposed correlation is the ${ }^{87} \mathrm{Sr} /{ }^{86} \mathrm{Sr}$ ratio versus the $\mathrm{Sr}$ content, which is much more in agreement with $\mathrm{H}_{2}$ than
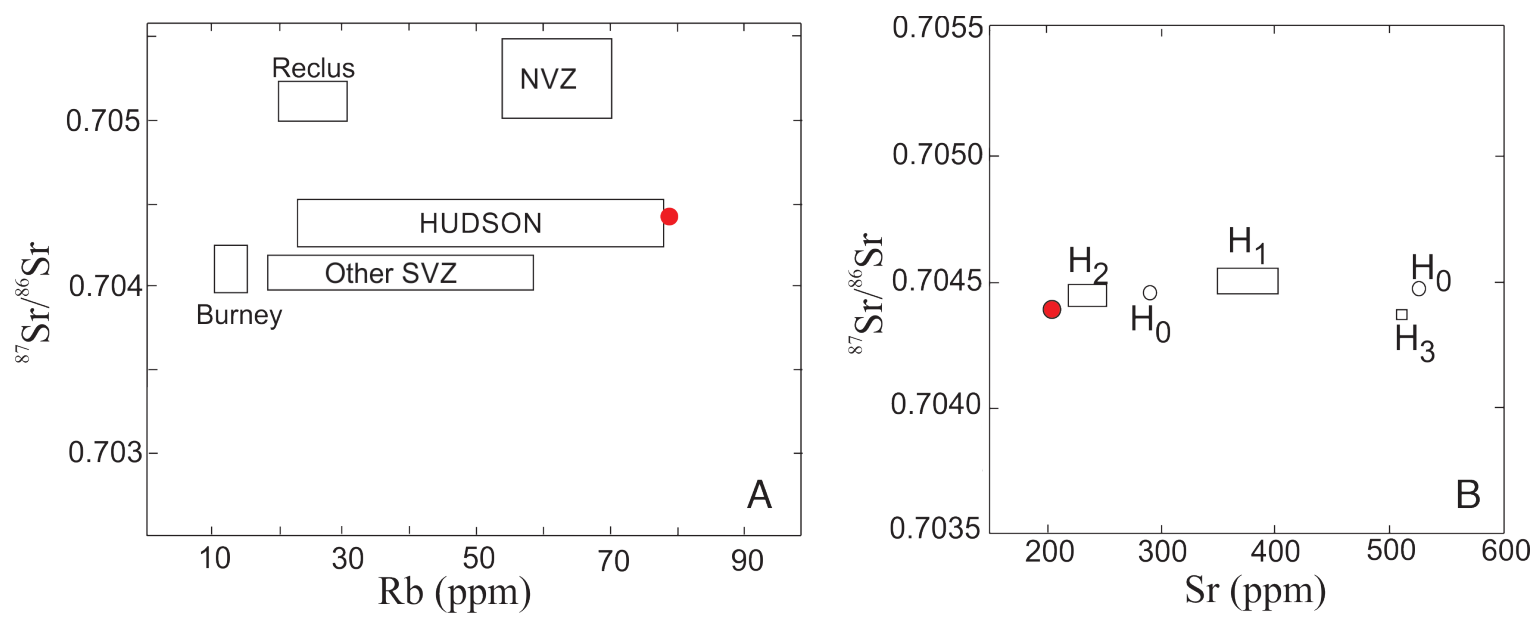

FIG. 5. A. ${ }^{87} \mathrm{Sr} /{ }^{86} \mathrm{Sr}$ versus $\mathrm{Rb}$ diagram, field for different volcanoes after Naranjo and Stern (1998); B. ${ }^{87} \mathrm{Sr} /{ }^{86} \mathrm{Sr}$ versus $\mathrm{Sr}$ diagram for the main Hudson explosive eruptions (after Weller et al., 2014). Burney and Reclus are from the Austral Volcanic Zone (Stern, 2008). Red point from Caleta Olivia tephra. 
the other major Hudson eruptions (Fig. 5; Naranjo and Stern, 1998). Overall, all the major, minor and trace element data support the notion that the Caleta Olivia tephra layer can be confidently correlated with Hudson volcano and $\mathrm{H}_{2}$ eruption is the best candidate, according to radiocarbon constraint and Sr-isotopes and trace element.

The finding of the Caleta Olivia tephra layer on top of a poorly developed paleosol suggests that deposition was facilitated by the presence of vegetation associated to the soil formation. The following developing of eolian deposition probably produced significant reworking of the tephra and the lentinticular shape visible today. An accumulation of reworked tephra and lithic aeolian sand may have locally preserved the tephra layers from subsequent dispersion. The general appearance of the outcrops can suggest that only the lower part $(\mathrm{ca} .5-6 \mathrm{~cm})$ may have experienced little or no reworking, as suggested by the fresh aspect and sharp edges of shards and the sorting (Fig. 3A, B). Therefore, $5 \mathrm{~cm}$ would a minimum possible estimated thickenss for the tephra layer, a value that needs to be considered with extreme care. However, a major important point is that this finding gives a clue to the extent of the original dispersion for the $\mathrm{H}_{2}$ Hudson eruption pyroclastic material (Fig. 1).

We note that Naranjo and Stern (1998), reported isopachs reconstruction for $\mathrm{H}_{2}$ eruption which are also more consistent with a dispersion toward $\mathrm{E}$, in agreement with our finding, in contrast to $\mathrm{H}_{1}$ and $\mathrm{H}_{3}$ which show a clearer dispersion toward SE (Fig. 1, see also Stern, 2008). The different dispersion may have been the expression of prevailing wind condition at time of the eruption, and/or changing in wind direction that may occur during the the paroxysmal Plinian eruption stages (see Kratzmann et al., 2010) or the occurrence of the eruption in a different season.

We note, that dispersion of the Late-glacial $\mathrm{H}_{0}$ tephra, is direct decisively toward NE (Weller et al., 2014), but Zanchetta et al. (2018b) found glass shards mixed with aeolian deposit with chemical composition compatible with $\mathrm{H}_{0}$ well south of the dispersion proposed by Weller et al. (2014). This indicates the high mobility of reworked glass shards in a windy climate with bare soils. In addition, we have to note that despite our intensive fieldwork in the area this was the only tephra identified within sedimentary coastal deposits. This is probably related to the poor capacity of preserving tephra layer in this environment. It is obvious that there is an underrepresentation of volcanic ash layers over this part of the Atlantic coastal area and this can probably underestimate our perception of volcanic risk based on the past distribution of tephra layers.

\section{Conclusion}

The finding of the Holocene tephra layer interbedded in the aeolian deposit north of Caleta Olivia represents an unique information on past volcanic ash dispersion over Atlantic coast of Patagonia. In particular chemical, Sr-isotopic and radiocarbon dating data allow correlating this layer with the $\mathrm{H}_{2}$ eruption from Hudson volcano (Naranjo and Stern, 1998). This allows documenting the extent to the east of the fine ash facies of that eruption, giving interesting information on potential dispersion of future explosive eruptions. This, in addition, contributes to the reconstruction of tephra lattice for this part of the Patagonian region for which information on the presence of tephra layers in the Quaternary successions is still scarce.

\section{Acknowledgments}

We thank J. Cause and the no-profit organization CADACE for the logistical support in the field campaign. This work was funded by the University of Pisa (Progetto Ateneo 2007, Leader G. Zanchetta; Progetto Ateneo PRA 2014 Leader G. Zanchetta) and MIUR (PRIN2008, Leader G. Zanchetta). We thank C. Stern and J. Naranjo for the useful comments and criticism which improved the quality of manuscript. We greatly appreciated the final revision of the Editor W. Vivallo.

\section{References}

Bini, M.; Isola, I.; Pappalardo, M.; Ribolini, A.; Favalli, M.; Ragaini, L.; Zanchetta, G. 2014. Abrasive notches along the Atlantic patagonian coast and their potential use as sea level markers: The case of Puerto Deseado (Santa Cruz, Argentina). Earth Surface Processes and Landforms 39: 1550-1558.

Bini, M.; Isola, I.; Zanchetta, G.; Pappalardo, M.; Ribolini, A.; Ragaini, L.; Baroni, C.; Borretto, G.; Fuck, E.; Morigi, C.; Salvatore, M.C.; Bassi, D.; Marzaioli, F.; Terrasi, F. 2018. Mid-Holocene relative sea-level changes along Atlantic Patagonia: New data from Camarones, Chubut, Argentina. The Holocene 28 (1): 56-64. 
Blockley, S.; Rasmussen, S.O.; Harding, P.; Brauer, A.; Davies, S.; Hardiman, M.; Lane, C.; Macleod, A.; Matthews I.; Wulf, S.; Zanchetta, G. 2014. Tephrochronology and the extended INTIMATE (Integration of ice-core, marine and terrestrial records) event stratigraphy 8-110 ka B2K. Quaternary Science Reviews 106: 88-100.

Caron, B.; Siani, G.; Sulpizio, R.; Zanchetta, G.; Paterne, M.; Santacroce, R.; Tema, E.; Zanella, E. 2012. Late Pleistocene to Holocene tephrostratigraphic record from the Northern Ionian Sea. Marine Geology 311-314: 41-51.

Castro, A. 2008. Sociedad aborígenes de Puerto Deseado antes de la conquista europea. In El área fundacional de Puerto Deseado: Estudios de Arqueología Histórica (Schavelzon, D.; editor). Buenos Aires de Los Cuatro Vientos: 105-121. Buenos Aires.

Cioni, R.; Marianelli, P.; Santacroce, R. 1997. Thermal and compositional evolution of the shallow magma chambers of Vesuvius: evidence from pyroxene phenocrysts and melt inclusions. Journal of Geophysical Research 103: 18277-18294.

Codignotto, J.O.; Marcomini, S.C.; Santillana, S.N. 1988. Terrazas marinas entre Puerto Deseado y Bahía Bustamante, Santa Cruz, Chubut. Revista de la Asociacion Geológica Argentina 43: 43-50.

Cordero, R.R.; Panarello, H.; Lanzelotti, S.; Favier Dubois, C.M. 2003. Radiocarbon age offsets between living organisms from the marine and continental reservoir in coastal localities of Patagonia (Argentina). Radiocarbon 45: 9-15.

Daga, R.; Ribeiro Guevara, S.; Sánchez, M.L.; Arribére, M. 2010. Tephrochronology of recent events in the Andean Range (northern Patagonia): spatial distribution and provenance of lacustrine ash layers in the Nahuel Huapi National Park. Journal of Quaternary Science 25 (7): 1113-1123.

Daga, R.; Ribeiro Guevara, S.; Poire, D.G.; Arribére, M. 2014. Characterization of tephras dispersed by the recent eruptions of volcanoes Calbuco (1961), Chaitén (2008) and Cordón Caulle Complex (1960 and 2011), in Northern Patagonia. Journal of South American Earth Sciences 49: 1-14.

Del Carlo, P.; Di Roberto, A.; D’Orazio, M.; Petrelli, M.; Angioletti, A.; Zanchetta, G.; Maggi, V.; Daga, R.; Nazzari, M.; Rocchi, S. 2018. Late Glacial-Holocene tephra from southern Patagonia and Tierra del Fuego (Argentina, Chile): A complete textural and geochemical fingerprinting for distal correlations in the Southern Hemisphere. Quaternary Science Reviews 195: 153-170.
Dioguardi, F.; Dellino, P. 2014. PYFLOW: a computer code for the calculation of the impact parameters of Dilute Pyroclastic Density Current (DPDC) based on field data. Computer Geoscience 66: 200-210.

Feruglio, E. 1950. Descripción geológica de la Patagonia, T. III. Dirección General de Yacimientos Petrolíferos Fiscales: 74-197. Buenos Aires.

Figari, E.G.; Strelkov, E.; Cid de la Paz, M.; Celaya, J.; Laffitte, G.; Villar, H. 2002. Cuenca del Golfo San Jorge: síntesis estructural, estratigráfica y geoquímica. In Geología y recursos naturales de Santa Cruz (Haller, M.J.; editor). Congreso Geológico Argentino, No. 15, Relatorio: 571-601. Buenos Aires.

Fontijn, K.; Lachowycz, S.M.; Rawson, H.; Pyle, D.M.; Mather, T.A.; Naranjo, J.A.; Moreno-Roa, H. 2014. Late Quaternary tephrostratigraphy of southern Chile and Argentina. Quaternary Science Reviews 89: 70-84.

Garreaud, R.D.; Vuille, M.; Compagnucci, R.; Marengo, J. 2009. Present-day South American climate. Palaeogeography, Palaeoclimatology, Palaeoecology 281: 180-195.

Goldstein, S.L.; Deines, P.; Oelkers, E.H.; Rudnick, R.L.; Walter, L.M. 2003. Standards for publication of isotope ratio and chemical data in Chemical Geology. Chemical Geology 202: 1-4.

Hunt, J.B.; Hill, P.G. 2001. Tephrological implications of beam size-sample-size effects in electron microprobe analysis of glass shards. Journal of Quaternary Science 16: 105-117.

Inbar, M.; Ostera, H.A.; Parica, C.A.; Remesal M.B.; Salani, F.M. 1995. Environmental assesment of 1991 Hudson volcano eruption ashfall effects on southern Patagonia region, Argentina. Environmental Geology 25: 119-125.

Inman, D.L. 1952. Measures for describing the sizedistribution of sediments. Journal of Sedimentary Petrology 22: 125-145.

Irvine, T.N.; Baragar, W.R.A. 1971. A guide to the chemical classification of the common volcanic rocks. Canadian Journal of Earth Sciences 8: 523-547.

Isla, F.I.; Bujalesky, G.G. 2008. Coastal geology and morphology of Patagonia and the Fuegian Archipelago. In The late Cenozic of Patagonia and Tierra del Fuego (Rabassa, J.; editor). Developments in Quaternary Science 11: 227-240.

Isola, I.; Bini, M.; Ribolini, A.; Pappalardo, M.; Consoloni, I.; Fucks, E.; Boretto, G.; Ragaini, L.; Zanchetta, G. 2011. Geomorphologic Map of Northeastern Sector of San Jorge Gulf (Chubut, Argentina). Journal of Maps 7: 476-485. 
Kratzmann, D.J.; Carey, S.N.; Scasso, R.A.; Naranjo, J.A. 2009. Compositional variations and magma mixing in the 1991 eruptions of Hudson volcano, Chile. Bulletin of Volcanology 71 (4): 419-439.

Kratzmann, D.J.; Carey, S.N.; Fero, J.; Scasso, R.A.; Naranjo, J.A. 2010. Simulations of tephra dispersal from the 1991 explosive eruptions of Hudson volcano, Chile. Journal of Volcanology and Geothermal Research 190: 337-352.

Le Bas, M.J.; Le Maitre, R.W.; Streckeisen, A.; Zanettin, B. 1986. A Chemical classification of volcanic rocks based on the total alkali-silica diagram. Journal of Petrology 27: 745-750.

Lowe, D.L. 2011. Tephrochronology and its application: a review. Quaternary Geochronology 6: 107-153.

Lowe, J.; Barton, N.; Blockley, S.; Ramsey, C.B.; Cullen, V.L.; Davies, W.; Gamble, C.; Grant, K.; Hardiman, M.; Housley, R.; Lane, C.S.; Lee, S.; Lewis, M.; MacLeod, A.; Menzies, M.; Müller, W.; Pollard, M.; Price, C.; Roberts, A.P.; Rohling, E.J.; Satow, C.; Smith, V.C.; Stringer, C.B.; Tomlinson, E.L.; White, D.; Albert, P.; Arienzo, I.; Barker, G.; Boric, D.; Carandente, A.; Civetta, L.; Ferrier, C.; Guadelli, J.L.; Karkanas, P.; Koumouzelis, M.; Müller, U.C.; Orsi, G.; Pross, J.; Rosi, M.; Shalamanov-Korobar, L.; Sirakov, N.; Tzedakis, P.C. 2012. Volcanic ash layers illuminate the resilience of Neanderthals and early modern humans to natural hazards. Proceedings National Academy of Science 109 (34): 13532-13537.

Marianelli, P.; Sbrana, A. 1998. Risultati di misure di standard di minerali e di vetri naturali in microanalisi a dispersione di energia. Atti Società Toscana Scienze Naturali, Memorie Serie A 105: 57-63.

Naranjo, J.A. 1991. Major eruption reported in Chile. EOS Transactions of the American Geophysical Union 72: 393-394.

Naranjo, J.A.; Stern, C.A. 1998. Holocene explosive activity of Hudson volcano, southern Andes. Bulletin of Volcanology 59: 291-306.

Naranjo, J.A.; Moreno, H.; Banks, N.G. 1993. La erupción del volcán Hudson en 1991 (46 S), Región XI, Aisén, Chile. Servicio Nacional de Geología y Minería, Boletín 44: 1-50.

Naranjo, J.A.; Singer, B.S.; Jicha, B.R.; Moreno, H.; Lara, L.E. 2017. Holocene tephra succession of PuyehueCordón Caulle and Antillanca/Casablanca volcanic complexes, southern Andes (40-41 $\left.{ }^{\circ} \mathrm{S}\right)$. Journal of Volcanology and Geothermal Research 332: 109-128.

Panza, J.L. 2002. La cubierta detrítica del Cenozoico Superior. In Geología y recursos naturales de Santa
Cruz (Haller, M.J.; editor). Congreso Geológico Argentino, No. 15, Relatorio: 259-284. Buenos Aires. Peccerillo, A.; Taylor, S.R. 1976. Geochemistry of Eocene calc-alkaline volcanic rocks from Kastamonu area, Northern Turkey. Contributions to Mineralogy and Petrolology 58: 39-63.

Prieto, A.; Stern, C.R.; Estévez, J.E. 2013. The peopling of the Fuego-Patagonian fjords by littoral hunter-gatherers after the mid-Holocene H1 eruption of Hudson Volcano. Quaternary International 317: 3-13.

Ramos, A.V.; Ghiglione, M.C. 2008. Tectonic evolution of the Patagonian Andes. In The late Cenozic of Patagonia and Tierra del Fuego (Rabassa, J.; editor). Developments in Quaternary Science 11: 57-71.

Rawson, H.; Naranjo, J.A.; Smith, V.; Fontijn, K.; Pyle, D.; Mather, T.; Moreno, H. 2015. The frequency and magnitude of post-glacial explosive eruptions at Volcán Mocho-Choshuenco, southern Chile. Journal of Volcanology and Geothermal Research 299: 103-129.

Reimer, P.J.; Bard, E.; Bayliss, A.; Beck, J.W.; Blackwell, P.G.; Bronk Ramsey, C.; Buck, C.E.; Cheng, H.; Edwards, R.L.; Friedrich, M.; Grootes, P.M.; Guilderson, T.P.; Haflidason, H.; Hajdas, I.; Hatta, C.; Heaton, T.J.; Hogg, A.G.; Hughen, K.A.; Kaiser, K.F.; Kromer, B.; Manning, S.W.; Niu, M.; Reimer, R.W.; Richards, D.A.; Scott, E.M.; Southon, J.R.; Turney, C.S.M.; Van der Plicht, J. 2015. IntCal13 and MARINE13 radiocarbon age calibration curves 0-50000 years cal BP. Radiocarbon 55: 1869-1887.

Ribolini, A.; Aguirre, M.; Baneschi, I.; Consoloni, I.; Fuck, E.; Isola, I.; Mazzarini, F.; Pappalardo, M.; Zanchetta, G.; Bini, M. 2011. Holocene Beach Ridges and Coastal Evolution in the Cabo Raso Bay (Atlantic Patagonian Coast, Argentina). Journal of Coastal Research 27: 973-983.

Rostami, K.; Peltier, W.R.; Mangini, A. 2000. Quaternary marine terraces sea-level changes and uplift history of Patagonia, Argentina: comparisons with predictions of the ICE-4G (VM2) model of the global processes of glacial isostatic adjustment. Quaternary Science Reviews 19: 1495-1525.

Scasso, R.A.; Corbella, H.; Tiberi, P. 1994. Sedimentological analysis of the tephra from the 12-15 August 1991 eruption of Hudson volcano. Bulletin of Volcanology 56: 121-132.

Schellmann, G.; Radtke, U. 2010. Timing and magnitude of Holocene sea-level changes along the middle and south Patagonian Atlantic coast derived from beach ridge systems, littoral terraces and valley-mouth terraces. Earth-Science Reviews 103: 1-30. 
Stern, C.R. 1991. Mid-Holocene tephra on Tierra del Fuego $\left(54^{\circ} \mathrm{S}\right)$ derived from the Hudson volcano $\left(46^{\circ} \mathrm{S}\right)$ : evidence for a large explosive eruption. Revista Geológica de Chile 18 (2): 139-146. doi: 10.5027/andgeoV18n2-a04.

Stern, C.R. 2004. Active Andean Volcanism: its geologic and tectonic setting. Revista Geológica Chile 31 (2): 161-206. doi: 10.5027/andgeoV31n2-a01.

Stern, C.R. 2008. Holocene tephrochronology record of large explosive eruptions in the southernmost Patagonian Andes. Bulletin of Volcanology 70: 435-454.

Stern, C.R.; Futa, K.; Muehlenbachs, K. 1984. Isotope and trace element data for orogenic andesites from the austral Andes. In Andean Magmatism: Chemical and Isotopic Constraints (Harmon, R.; Barreiro, B.A.; editors). Shiva Geology Series, Shiva Publishing Limited: 31-46. Cheshire, UK.

Stern, C.R.; Moreno, P.I.; Villa-Martínez, R.; Sagredo, E.A.; Prieto, A.; Labarca, R. 2011. Evolution of icedammed proglacial lakes in Última Esperanza, Chile: implications from the late-glacial R1 eruption of Reclus volcano, Andean Austral Volcanic Zone. Andean Geology 38 (1): 82-97. doi: 10.5027/andgeoV38n1-a06.

Stern, C.R.; de Porras, M.A.; Maldonado, A. 2015. Tephrochronology of the upper Río Cisnes valley $\left(44^{\circ} \mathrm{S}\right)$, southern Chile. Andean Geology 42 (2): 173-189. doi: 10.5027/andgeoV42n2-a02.

Stern, C.; Moreno, P.; Henríquez, W.; Villa-Martínez, R.; Sagredo, E.; Aravena, J.; De Pol-Holz, R. 2016. Holocene tephrochronology around Cochrane ( $47^{\circ}$ S), southern Chile. Andean Geology 43 (1): 1-19. doi: 10.5027/andgeoV43n1-a01.

Sulpizio, R.; Zanchetta, G.; Caron, B.; Dellino, P.; Mele, D.; Giaccio, G.; Insinga, D.; Paterne, M.; Siani, G.; Costa, G.; Macedonio, G.; Santacroce, R. 2014. Volcanic ash hazard in the Central Mediterranean assessed from geological data. Bulletin of Volcanology, Springer Verlag 76 (10): 866 p. doi: 10.1007/s00445-014-0866-y.

Sylwan, C.A. 2001. Geology of the Golfo San Jorge Basin, Argentina Geología de la Cuenca del Golfo San Jorge, Argentina. Journal of Iberian Geology 27: 123-157.

Terrasi, F.; Rogalla, D.; De Cesare, N.; D’Onofrio, A.; Lubritto, C.; Marzaioli, F.; Passariello, I.; Sabbarese, C.; Casa, G.; Calmieri, A.; Gialanella, L.; Imbriani, G.; Roca, V.; Romano, M.; Sundquist, M.; Loger, R. 2007. A new AMS facility in Caserta/Italy. Nuclear Instruments and Methods in Physics Research B 259: 14-17.

Terrasi, F.; De Cesare, N.; D’Onofrio, A.; Lubritto, C.; Marzaioli, F.; Passariello, I.; Rogalla, D.; Sabbarese, C.;
Borriello, G.; Casa, C.; Palmieri, A. 2008. High precision ${ }^{14} \mathrm{C}$ AMS at CIRCE. Nuclear Instruments and Methods in Physics Research 266: 2221-2224.

Vogel, H.; Zanchetta, G.; Sulpizio, R.; Wagner, B.; Nowaczyk, N. 2010. A tephrostratigraphic record for the last glacial-interglacial cycle from Lake Ohrid, Albania and Macedonia. Journal of Quaternary Science 25 (3): 25 p. doi: 10.1002/jqs.1311.

Watt, S.F.L.; Pyle, D.M.; Mather, T.A. 2013. Evidence of mid- to late-Holocene explosive rhyolitic eruptions from Chaitén Volcano, Chile. Andean Geology 40 (2): 216-226. doi: 10.5027/andgeoV40n2-a02.

Weller, D.; Miranda, C.; Villa-Martínez, R.; Stern, C. 2014. The large lateglacial $\mathrm{H}_{0}$ eruption of the Hudson volcano, southern Chile. Bulletin of Volcanology 76: 831-850.

Weller, D.; Miranda, C.; Moreno, P.; Villa-Martínez, R.; Stern, C. 2015. Tephrochronology of the southernmost andean southern volcanic zone, Chile. Bulletin of Volcanology 77: 1-24.

Weller, D.J.; De Porras, M.E.; Maldonadoc, A.; Méndez, C.; Stern, C.R. 2019. Petrology, geochemistry, and correlation of tephra deposits from a large early-Holocene eruption of Mentolat volcano, southern Chile. Journal of South American Earth Sciences 90: 282-295.

Zanchetta, G.; Sulpizio, R.; Giaccio, B.; Siani, G.; Paterne, M.; Wulf, S.; D’Orazio, M. 2008. The Y-3 tephra: a Last Glacial stratigraphic marker for the central Mediterranean basin. Journal of Volcanology and Geothermal Research 177: 145-154.

Zanchetta, G.; Consoloni, I.; Isola, I.; Pappalardo, M.; Ribolini, A.; Aguirre, M.; Fucks, E.; Baneschi, I.; Bini, M.; Ragaini, L.; Terrasi, F. 2012a. New insights on the Holocene marine transgression in the Bahía Camarones (Chubut, Argentina). Italian Journal of Geoscience 131: 19-31.

Zanchetta, G.; Giraudi, C.; Sulpizio, R.; Magny, M.; Drysdale, R.N.; Sadori, L. 2012b. Constraining the onset of the Holocene "Neoglacial" over the central Italy using tephra layers. Quaternary Research 78: 236-247.

Zanchetta, G.; Bini, M.; Isola, I.; Pappalardo, M.; Ribolini, A.; Consoloni, I.; Boretto, G.; Fucks, E.; Ragaini, L.; Terrasi, F. 2014. Middle-to late-Holocene relative sea-level changes at Puerto Deseado (Patagonia, Argentina). The Holocene 24: 307-317.

Zanchetta, G.; Giaccio, B.; Bini, M.; Sarti, L. 2018 a. Tephrostratigraphy of Grotta del Cavallo, Southern Italy: insights on the chronology of Middle to Upper Palaeolithic transition in the Mediterranean. Quaternary Science Reviews 182: 65-77. 
Zanchetta, G.; Ribolini, A.; Ferrari, M.; Bini, M.; Isola, I.; Lezzerini, M.; Baroni, C.; Salvatore, M.C.; Pappalardo, M.; Fucks, E.; Boretto, G. 2018b. Geochemical characteristics of the infilling of ground wedges at Puerto Deseado (Santa Cruz, Argentina): palaeoenvironmental and chronolog- ical implications. Andean Geology 45 (2): 130-144. doi: 10.5027/andgeoV45n2-3070.

Zanchetta, G.; Bini, M.; Di Vito, M.A.; Sulpizio, R.; Sadori, L. 2019. Tephrostratigraphy of paleoclimatic archives in central Mediterranean during the Bronze Age. Quaternary International 499: 186-194.

Manuscript received: August 02, 2019; revised/accepted: October 23, 2020; available online: January 29, 2021. 